\title{
Judíos y conversos de El Puente del Arzobispo (Toledo) en la Edad Media
}

\author{
Gonzalo Viñuales Ferreiro *
}

\begin{abstract}
RESUMEN
ABSTRACT

En la villa de El Puente del Arzobispo

In the village of El Puente del

(Toledo) existió una pequeña Arzobispo (Toledo) lived a little jewish comunidad judia durante el siglo $\mathrm{XV}$, muchos de cuyos miembros salieron de Castilla en dirección a Portugal en

1492 tras el decreto de expulsión de los judios, y al poco tiempo regresaron

como cristianos a esta localidad reclamando los bienes que les habian pertenecido en el pasado cuando eran community during the fifteenth century, where, after the jews expulsion decree-law in 1492, many of the jews left the place to Portugal, and only a few years later they came back to this village and reclaimed all the properties that they had when they lived there like jews.

judios.
\end{abstract}

La actual localidad de El Puente del Arzobispo está situada en la parte occidental de la provincia de Toledo distando $150 \mathrm{~km}$. de Madrid, $30 \mathrm{~km}$. de Talavera de la Reina, y 117 km. de Toledo. En las Relaciones... 1, hechas en 1576, se expone que pertenecia al Reino de Toledo, ubicada al norte del río Tajo, de tal modo, que sus pleitos habían de dirimirse en la Audiencia-Chancillería de Valladolid, a una distancia de 30 leguas de la raya de Portugal. Era todavía por entonces señorío eclesiástico y civil de los arzobispos de Toledo. El terreno es llano con pequeñas alturas (la altitud máxima alcanza tan sólo los 320 metros), y tímidamente se observa un aumento del relieve en la zona meridional en dirección hacia la Sierra de Altamira. Dicen las mentadas Relaciones que la tierra es llana, aunque alrededor de la villa

* Departamento de $H^{a}$ Medieval, $H{ }^{9}$ Moderna, y Ciencias y Técnicas Historiográficas. UNED.

1 VIÑAS, C., y PAZ, R.: Relaciones histórico-geográfico-estadísticas de los pueblos de España hechas por iniciativa de Felipe II, Madrid, 1949, pp. 281-297. 
haya algunos pequeños montes. Respecto al clima afirman que no es «... tierra fría, sino caliente y sana...».

La reducida extensión de su término municipal, que no supera los $0,63 \mathrm{~km}^{2}$, convierte a esta villa en la población española con el término municipal más pequeño. De nuevo aludimos a las Relaciones topográficas con ocasión de la descripción de sus límites, y nos presentan una imagen semejante a ésta: al norte, la villa de Oropesa; al oriente, las villas de Alcolea de Tajo y Azután; hacia el sur, hallamos Valdelacasa y Valdeverdeja; y al occidente, la villa de El Torrico. Siempre ha vivido la villa a expensas de su producción interior, de las concordias con las tierras comarcanas y de los cuantiosos beneficios que reportaba el puente.

La población puenteña alcanzaba en 1990 los 1.578 habitantes, después de haber superado la cota de los 2.000 vecinos en 1970. De acuerdo a los padrones de 1578, en la localidad de El Puente del Arzobispo habitaban de 400 a 500 vecinos, lo que nos permite aventurar el reducido número de pobladores que tendría la villa aproximadamente unos cien años antes.

Pertenece al partido judicial de Talavera de la Reina, y está situada dentro de la comarca natural del Campo Arañuelo, que se corresponde con la cuenca sedimentaria del valle centro-occidental del Tajo ${ }^{2}$, englobada dentro de la llamada Jara Toledana.

Aunque la antigüedad histórica de la comarca nos remonta hasta fechas de ocupación paleolítica, y a expensas de los diversos asentamientos que en épocas sucesivas se han documentado arqueológicamente (ibéricos, romanos, visigodos, e islámicos), esta localidad toledana nació gracias al impulso que el arzobispo de Toledo don Pedro Tenorio hizo, a finales del siglo XIV, en relación a la construcción de un puente que permitiera vadear el río Tajo con más facilidad que en otros lugares, especialmente por tres motivos: uno económico, ya que favorecería el desarrollo de las rutas de transhumancia; otro, socio-cultural, pues el auge que estaba empezando a cobrar la peregrinación al monasterio cacereño de Santa María de Guadalupe, necesitaba urgentemente de buenas vías de comunicación 3; y por último, uno de carácter militar, pues las guerras con Portugal del rey don Pedro habían demostrado las numerosas dificultades que imponía el cruce del Tajo entre Talavera y Alcántara.

2 Otros autores denominan a esta comarca como Tierra de Talavera. Vid. GonzALEZ, Elena, y PILLET, Félix: Geografia física, humana y económica de Castilla-La Mancha, Ciudad Real, 1986, p. 60.

3 El rey Juan I elogia la iniciativa arzobispal por la importancia que conlleva la construcción del puente, “... fue un gran serviçio de Dios, e una de las más notables cosas que en nuestro reinado se hizo, y espeçialmente por se hacer en el río Tajo, en lugar muy neçesario, e muy cumplidero al serviçio de Dios y en el nuestro e provecho de todos...". Vid. JiMÉnEZ DE GREGORIO, Fernando: Historia de la Villafranca de la Puente del Arzobispo, Toledo, 1990, p. 23. 
La tradición, siempre más profana e imaginativa, cuenta que el origen del puente, y con él de la villa, partió de un paseo ribereño que el arzobispo realizaba un buen día, cuando un vecino, observando el elevado caudal del río, le preguntó al prelado que cuándo iba a levantar un puente que uniera ambas orillas para facilitar el tránsito entre las riberas. El obispo, poco convencido de su necesidad tentó a la suerte arrojando su anillo al cauce del río, afirmando que no construiría dicha construcción hasta que el río le devolviera su anillo pastoral. Al mediodía siguiente, en el almuerzo, el obispo comenzó a degustar un barbo recién pescado, y al abrirlo, encontró intacto el anillo que había arrojado al agua el día anterior.

Aprovechando un estrechamiento del cauce del Tajo, en 1380 se inician las obras del puente de piedra. Los comienzos no fueron sencillos. Primero, por la necesidad urgente de mano de obra especializada en canteria y encalados. En segundo lugar, debido a las enérgicas protestas de la comunidad de monjas del monasterio de San Clemente. Éstas regentaban desde mediados del siglo XIII, por privilegio real, la explotación del cercano puente de madera conocido como el Puente de Pinos. La edificación de un puente de piedra lastimaría definitivamente sus intereses, ya que todos los ganados y peregrinos que atravesaban el Tajo por este puente, se trasladarían hacia el nuevo. Presentadas sus quejas ante el rey Juan I, se buscó una solución intermedia mediante la conciliación de Clemente VII, papa en Avignon. Ambas partes aceptaron la concordia propuesta: el arzobispo podría edificar su puente, y en compensación debería entregar a las monjas de San Clemente 300 carneros y 300 ovejas cada año, cantidad en que se estimó el valor del Puente de Pinos ${ }^{4}$.

En 1388 ya estaba levantado el puente sobre el Tajo. Los palacios del arzobispo don Pedro Tenorio debieron ser las primeras construcciones de esta ribera, que se vieron aumentadas con las diversas y humildes viviendas de los trabajadores contratados para la construcción. Para que el puente no se quedara desguarnecido, el rey Juan I concedió franqueza en $1390^{5}$ tanto a los que ya vivían allí como a los posibles nuevos moradores.

No sólo trabajó el arzobispo en la construcción del puente. También fundó los hospitales para pobres y forasteros cercanos al puente. Aunque se dotó de capilla a estos hospitales, la continua llegada de población la convirtió en insuficiente, por lo que don Pedro mandó levantar el templo de

4 Vizuete Mendoza, J. Carlos: “El monasterio de San Clemente en la Edad Media. (Los documentos reales. Estudio y regesta)", en Anales Toledanos, XXX (1993), pp. 31-32.

5 «... Fue nuestra merced de poner nombre a que fuese llamado Pueblo, que a el fuere poblado Villafranca de la Puente del Arzobispo ... en que fuese franco e quito de todos los pechos e servicios y monedas $y$ alcabalas e galeotes $e$ lanceros e ballesteros e carreteros e pedreros e guias e qualquier pechos e tributos e derramientos e tasas...". Vid. JIMÉNEZ DE GREGORIO, Fernando: op. cit., p. 37. 
Santa Catalina. A su vez, impulsó el crecimiento de la villa mediante la construcción de molinos harineros, de un batán, y con la puesta en explotación de diversas dehesas. Y además, concedió al concejo el cobro de los diezmos y el pontazgo lo que redundaría en nuevos y cuantiosos ingresos.

El siglo xv estuvo marcado por el despertar económico y político de la villa. Cruce de caminos, de ganados y de reyes, entre los acontecimientos de mayor relevancia histórica hemos de destacar el encuentro que en 1464 se produjo en la villa entre Enrique IV de Castilla y Alfonso V de Portugal, en el que se acordó el casamiento de la infanta Isabel, futura Isabel I, con el monarca portugués, matrimonio que nunca llegó a celebrarse.

\section{LOS JUDIOS DE EL PUENTE DEL ARZOBISPO}

La tardía fundación de la "Villafranca de la Puente del Arzobispo" (Toledo) solamente nos permite contar con noticias sobre sus judíos a partir del siglo XV. Los datos que poseemos acerca de esta juderia son relativamente escasos, y su importancia debió ser bastante reducida según se desprende de las cantidades que pagaban en los repartimientos fiscales de la segunda mitad del siglo. No obstante no es de extrañar, debido a las buenas relaciones entre el arzobispo de Toledo y los judios ${ }^{6}$, que diversos hebreos se trasladaran en los mismos años de su fundación a esta población, que contaba con excelentes facilidades y privilegios de poblamiento. Además, coincidió esta época con el momento de máximo antisemitismo en Castilla (pogrom de 1391), lo que obligó a muchos judíos a buscar refugio en lugares de señorío mejor guarnecidos.

Hemos de esperar hasta el año 1450 para gozar de información sobre judíos habitantes de El Puente del Arzobispo. De acuerdo a los remates de rentas del arzobispado, que se conservan en el Archivo de la Catedral de Toledo, ese año se adjudicó el cobro de los 30 dineros que pagaban los judíos, a Ferrán García Rojo, a cambio de 75 maravedíes de moneda vieja 7 . Como recuerdo de la entrega que Judas Iscariote hizo de Jesucristo por 30 monedas de plata, los judíos estaban obligados a pagar a la Iglesia, treinta dineros anualmente. Era un impuesto de escasa cuantia, cobrado en Castilla, al menos desde $1238^{8}$, que no obstante, recalcaba la supremacía de la Iglesia, y del Cristianismo, por encima de los judíos.

6 El arzobispo contaba con médicos judíos, pues en 1398 nombra a su físico, Rabí Hayim, juez de las aljamas del arzobispado de Toledo. $Y$ en su testamento también se alude a diversos regalos con que el judío don Abrahem Abenxuxén le obsequió al prelado una Navidad. Vid. LEÓN TELLO, Pilar: Judíos de Toledo, vol. I, p. 427, Doc. 38.

7 LEÓN TELLO, Pilar: op. cit., vol. II, p. 272. 
Respecto a la juderia de El Puente del Arzobispo no podemos ofrecer sino unas someras indicaciones. En la villa, de la que solamente tenemos constancia de que fuera aljama el año de 1484, existía una sinagoga. Según un contrato de censo firmado en 3 de agosto de 1473, entre Ferrand Alfón, visitador de Talavera, y Haynd Zubel, y Esther, su mujer, éstos hipotecan «... unas casas que tienen en Villafranca que lindan con la sinagoga, y la calle real...", para poder pagar el censo de una viña en el pago llamado de la Alameda, en el camino que conduce hacia Talavera ${ }^{9}$. Es ésta la única alusión topográfica del posible emplazamiento urbano del templo judío, pues en este caso, en El Puente del Arzobispo se continúa denominando a una calle como Calle Real, de tal forma, que no haría referencia a una calle pública cualquiera ${ }^{10}$.

Otra de las reducidas noticias acerca de la sinagoga de El Puente la obtenemos a partir del proceso que el Tribunal Inquisitorial de Toledo en 1489 siguió contra Inés González, judeoconversa, mujer de Luis González, tejedor, y ya fallecida para esos años. Entre los testigos que declaran acusando a esta criptojudia, encontramos al judío de El Puente del Arzobispo, Mosé Alvane, que depone que «... conosçió a su muger de Luis González, vecina de la Puente, difunta, e que muchas vezes preguntaba que quando era el ayuno mayor $y$ otros ayunos e que muy públicamente los ayunava e sabe que echava azeyte en la Xinoga, sábelo porque lo vido...»11.

Con motivo de la expulsión de los judíos de Castilla, los bienes comunes que pertenecían a esta minoría pasaron a manos reales. En muchas ocasiones, los monarcas compensaron diversos servicios y ayudas con el traspaso de estos bienes a particulares. El arzobispo de Toledo era el señor de El Puente del Arzobispo. A la sazón, el Cardenal Mendoza, primado de España, recibió por merced real «... los bienes de los judíos de las villas de logares del Arçobispado de Toledo de la Xinoga de la Puente del Arçobispo e con el prado e casas e corrales e con todas las otras casas que son anexas a la dicha Xinoga...” 12. En este caso, la importancia de la sinagoga, como centro de la judería resulta evidente, pues se asocian las propiedades comunales de la comunidad judia de El Puente del Arzobispo a esta institución.

Los últimos datos que conocemos relativos a la sinagoga de la comunidad hebrea de El Puente del Arzobispo, se insertan dentro del proceso inqui-

8 La referencia documental más antigua que conservamos en Castilla del pago judío de los 30 dineros pertenece a la comunidad judia de la villa toledana de Maqueda, en 1238. Es posible que esta tributación se viniera cobrando con anterioridad. Vid. VIÑUALES FERREIRO, Gonzalo: "Maqueda 1492: judios y judaizantes", en Espacio, Tiempo, y Forma, 11 (1998), Serie III, H. Medieval, pp. 383-404.

9 LEON TELLo, Pilar: op. cit., vol. II, p. 415.

10 JIMÉNEZ DE GREGORIO, Fernando: op. cit., p. 63.

11 AHN. INQ. Leg. 154. Exp. 4.

12 AGS. RGS. Fol. 5. [1495, mayo, 9.] 
sitorial que siguió el Santo Oficio contra el judeoconverso Francisco de Torres entre 1530 y 1531. Según se desprende de la declaración que Juan Martín, zapatero converso de la citada villa, realizó el 27 de enero de 1515, sabemos que un día de 1506 acudió a comer a casa del procesado quien «... en acabando de comer, demandó a una hija suya que se llama Catalina que está casada con Francisco Redondo, çapatero, veçino de la dicha villa, una vigüela e entonando se la començó el dicho Francisco de Torres a tañer e cantar un cantar que solian cantar los judios en la Xinoga antes que començase la oraçión por las mañanas e que el dicho cantar cantaba en hebrayco e que no sabe que palabras dezia en el dicho cantar más de quanto sabe que el dicho cantar cantavan los judíos en la Xinoga como dicho tiene..." 13.

La otra institución comunal judia que hemos documentado en esta localidad toledana es el cementerio judío. Como tal, estaba ubicado fuera del recinto urbano en algún lugar elevado ${ }^{14}$. Sabemos que había que cruzar el río Tajo por el puente para poder acceder al cementerio, que estaba situado próximo a una tierra de los hospitales de la villa. Conocemos esta información gracias a la sentencia que el entregador de la Mesta, Bartolomé Figueroa, mandado por el Honrado Concejo, obligaba a la villa de El Puente del Arzobispo a abrir la cañada de transhumancia que el concejo puenteño había cerrado. El citado entregador, junto con el alcalde mayor, hubo de delimitar la vía pecuaria amojonando los términos. Entre los linderos «... por el río Tajo, cerca de la tierra de los hospitales, siguieron amojonando pasado el puente, hasta dar con el fosal de los judios..." 15. También limitaba con tierras de judios de la localidad, pues los citados oficiales de la Mesta, «... entrando en la cañada en dirección a Alcolea encontraron, entre otras, viñas de Semuel de Frómista, y viñas de Sabel, judío...»16.

Los judíos vivirían insertos en el cuerpo de la villa ${ }^{17}$. Carecemos de noticias acerca de sus casas y viviendas. Sin embargo, sabemos, por las $R e$ laciones topográficas..., que las viviendas eran muy sencillas («pobres edificios»), con base de piedra pero con tapiales de ladrillo o tierra.

La importancia estratégica de la villa en virtud del paso de los ganados mesteños, como hemos visto, se manifiesta de nuevo en 1472, aunque de forma indirecta. Dos judíos villafranquenses, Rabí Yento Arragel, e Ysaque

13 AHN. INQ. Leg. 186. Exp. 1

14 Recordemos que según las prescripciones talmúdicas los camposantos judios debían ubicarse en el exterior del recinto de la ciudad a una distancia entre 50 metros y 2 kilómetros, y en algún monte cercano. Vid. CANTERA MONTENEGRo, Enrique: Aspectos de la vida cotidiana de los judíos en la España medieval, Madrid, 1998, pp. 168-171.

15 LEON TELLO, Pilar: op. cit., vol. II, pp. 309-310.

16 Ibidem.

17 Ya hemos citado como los judíos Haynd Zubel y su mujer, Esther, vivian en unas casas que limitaban con la sinagoga de la villa y con la calle real. 
Barchilón, aparecen como testigos en el conflicto que el concejo de la Mesta, y el conde de Miranda, a la sazón, don Diego de Estúñiga, tienen en relación con el paso de los ganados del puerto del Verrocalejo de Talavera, y diversas rentas ${ }^{18}$. No había sido ésta, la primera ocasión en que se habian enfrentado el concejo o alguno de sus habitantes con la poderosa institución ganadera. Julius Klein en su famosa obra sobre la Mesta, ya transcribía un documento, fechado en 1 de junio de 1457, en el que realizaba el amojonamiento de una cañada, impidiendo los cercados en torno a la misma. Entre las propiedades que limitaban con dicha vía pecuaria se mencionan viñas de Jubel, judío vecino de la Puente, Simuel de Frómista, y de Rabí Moço ${ }^{19}$.

Conocemos más pleitos en relación a judíos de la localidad. El más significativo es el que se presenta en la Audiencia de Valladolid en 1492. Se había iniciado en la villa del Colmenar de Arenas, ante el bachiller Alonso Pérez, alcalde en esa ciudad, y se disputaba entre Juan de Corrales, vecino de Navarredonda, y Rabí Sento Çeruela, vecino de El Puente del Arzobispo, sobre razón que el dicho judío le puso a Juan de Corrales una demanda «... diciendo que el judío era serviciador del servicio y montazgo de los ganados del travieso de Talavera y el arciprestazgo de Escalona, y las dehesas de Alamin e la vicaría de la Puebla de Alcocer, desde san Juan de junio del año que pasó de ochenta e ocho años hasta el mismo día del noventa e dos, diciendo que Juan de Corrales metió el año que pasó de ochenta e ocho años, 134 carneros sin las diligencias de la ley del servicio y montazgo..." 20. Por este motivo solicitaba que se le entregara tanto el ganado como el abono de las costas del proceso. El alcalde Alonso Pérez condenó a Juan de Corrales a que entregara al judío los 134 carneros que estaban en el puerto de Ramacastañas, o en compensación, 150 mrs. por cada uno.

Sin embargo, en la Chancillería la resolución adoptada será bien distinta, pues se obliga a Rabí Sento Çeruela a devolver los 60 carneros que ya le había tomado a Juan de Corrales. Mientras, le exigen al bachiller Alonso Pérez que pague las costas del juicio, fijadas en $3.643 \mathrm{mrs}$.

La conexión de la villa de El Puente del Arzobispo con la importante aljama de la cercana villa de Talavera de la Reina, también perteneciente a la jurisdicción arzobispal de Toledo fue evidente. El 7 de noviembre de 1470 , Ferrand Alfonso, que era administrador de los hospitales de El Puente com-

18 Archivo de la Colegiata de Talavera, (en adelante, AColT). Caja 271, n. ${ }^{\circ} 2$. Vid. LEón Tello, Pilar: op. cit, vol. II, p. 405.

19 KLEIN, Julius: La Mesta, Madrid, 1979, pp. 384-389.

20 Archivo de la Real Chancillería de Valladolid. Ejecutorias. Caja 49. Exp. 5. 
praba a don Mosé Namias, y a doña Clara, su mujer, una viña situada en la Almojeda, camino de Talavera a Traserranos ${ }^{21}$.

Simuel de Frómista es el judío mejor documentado de esta villa. Debió de ser uno de los principales personajes hebreos de esta localidad. No en vano, aparte de su influyente posición económica, sabemos que vivía muy cerca de la sinagoga, lo que sin duda era muestra de su prestigio 22 . Su riqueza debía ser patente, pues el 11 de septiembre de 1469, varios individuos entraron a robar en su casa de La Estrella (de la Jara), pueblo cercano a EI Puente del Arzobispo, y entre su botín se llevaron una taza de plata, un caballo, y $50.000 \mathrm{mrs}$. aparte de secuestrar con ellos a Abraham, hijo de don Simuel, a un sobrino y a Alfonso de Olivares ${ }^{23}$.

Entre 1458 y 1469 fue arrendador de los tributos de la Santa Hermandad Vieja de Talavera de la Reina ${ }^{24}$. En 1457 había ofrecido 20.000 mrs. por el arrendamiento del famoso puente de la villa; y en 1462, pujaba con $47.000 \mathrm{mrs}$. sobre la renta de la asadura de la Santa Hermandad de Talavera ${ }^{25}$. Ese mismo año, ya había tenido un enfrentamiento con la Mesta acerca del paso de ganados por la Cañada Real que ocupaban tierras de su propiedad 26 . Entre 1474 y 1479 , aparece este rico judío como rematador de los impuestos de un tal Pedro de la Lora, vecino de Talavera de la Reina. Él sería nominalmente el recaudador, mientras que le ayudaban en el cobro Yuçef Estorgano e Ysaque Abengato ${ }^{27}$.

En 1475, el judío establece un contrato de censo con Francisco de $\mathrm{Me}$ neses de 1.000 mrs. sobre unas tierras en Fuente Lapio. No obstante, en 28 de enero de 1478, Alfonso Ferrández, procurador de Francisco Meneses, vecino de Talavera, ha de tomar una heredad y casas del citado judio, pues no había abonado el censo estipulado que tenía sobre esos bienes en $1.000 \mathrm{mrs}^{28}$. De acuerdo a las listas de arrendamiento de impuestos de la Catedral de Toledo, aparece junto a don Frayme Almale como arrenda-

21 LEÓN TELLo, Pilar: op. cit., vol. II, p. 395.

22 Los judios de El Puente del Arzobispo, Haynd Zubel y Esther, ofrecen como garantía de un contrato de censo, unas casas que poseen “... en esta villa que alindan de la una parte con casas de don Simuel de Frómista..., y por la otra parte con la Sinoga, e por la otra parte, con la calle Real...". Vid. AColT. Caja 271, n. $^{\circ} 5$.

23 SÁNCHEZ BENITO, José María: Santa Hermandad Vieja de Toledo, Talavera y Ciudad Real (siglos XII-XV), Toledo, 1987, p. 271

24 SÁNCHEZ Benito, José María: op. cit., p. 212.

25 SÁnCHEZ BEnITO, José María: Colección de documentos de la Santa Hermandad (1300-1500), Toledo, 1990, n.o 256.

26 KLEIN, Julius: op. cit., pp. 384-389.

27 LEÓN TELLO, Pilar: op. cit., vol. II, p. 435.

28 LEÓN TELLO, Pilar: op. cit., vol. II, p. 453. 
dor de Villajero de las Fuentes en $1481^{29}$. Y en 1488, será arrendador de las alcabalas del maestrazgo de Alcántara y Badajoz ${ }^{30}$.

Y junto a él, vivía en la localidad su hermano, Ysaque de Frómista, quien en 1478 le daba poder a Pedro de la Cava, «... para que le obligue junto a su hermano en contía de 1.190 mrs. con los derechos de los aliceres, en la renta de los vestuarios..." 31 .

No siempre soplaron en la villa vientos de convivencia pacífica entre cristianos y judíos. No obstante, los datos que conocemos aluden a circunstancias concretas motivadas por robos o pleitos. En 6 de junio de 1457, Abrahem Astorgano, en nombre de Simuel de Frómista, denuncia ante el cabildo de la Santa Hermandad, que con motivo del cobro de la renta de la asadura de la Santa Hermandad de Talavera correspondiente a ese año, acudió a la villa de El Puente del Arzobispo, y alli fue «... molestado, injuriado y apresado ..." 32. Hemos hablado anteriormente del robo que en 1469 sufrió Simuel de Frómista en su casa de La Estrella.

Y en 1490, el judío puenteño Jácome Chachuelo fue apresado por un emisario de la duquesa de Plasencia, en virtud del pleito que existía entre Fernando de Monroy, señor de Almaraz, y la citada duquesa, sin tener el judio ninguna culpa ni responsabilidad en ese proceso ${ }^{33}$.

Uno de los más importantes indicadores de la importancia de una judería o aljama es la cantidad que aportaban en los repartos específicos del "servicio y medio servicio", "cabeza de pecho", y "castellanos de oro", que solamente gravaba a las minorías mudéjar y judía. Se conservan bastantes listas de estos repartimientos para la segunda mitad del siglo XV. De su lectura se desprende la reducida capacidad y significación que tenía la judería de El Puente del Arzobispo, pues las contribuciones que aporta son realmente escasas, en el contexto de las demás juderias de Castilla. Sirva como ejemplo el repartimiento del "servicio y medio servicio" del año 1484, única ocasión en que se nombra a la judería de El Puente del Arzobispo como aljama. Ese año, los judíos de Castilla abonaron $446.100 \mathrm{mrs}$. a la Hacienda Real, participando las aljamas y juderías de la diócesis de Toledo con la cuantiosa cifra de $66.000 \mathrm{mrs}$. Pues bien, de esos $66.000 \mathrm{mrs}$. la aljama de esta localidad toledana sólo aportó $500 \mathrm{mrs}$., lo que supone sola-

29 BAER, Fritz: Die Juden im Christlichem Spanien. Kastilien e Inquisitionakten, Berlín, 1936, tomo II, p. 347.

30 BAER, Fritz: op. cit., p. 387

31 SUÁREZ BILBAO, Fernando: Las ciudades castellanas y sus juderias en el siglo XV, Madrid, 1995, p. 226.

32 SÁnchez Benito, José María: Colección de documentos de la Santa Hermandad, Toledo, 1990 , p. 73, n. ${ }^{\circ} 181$.

33 LeON TEllo, Pilar: op. cit., vol. II, p. 546. 
mente un $0,75 \%$ del conjunto de las juderías de esta amplia demarcación territorial.

En el siguiente cuadro hemos reflejado por años las contribuciones que, tanto en concepto de "servicio y medio servicio", como en concepto de "castellanos de oro", ingresaron los judíos de El Puente del Arzobispo ${ }^{34}$ :

\begin{tabular}{cc}
\hline AÑO & CANTIDAD \\
\hline 1464 & 1.000 \\
\hline 1472 & 1.800 \\
\hline 1474 & 1.450 \\
\hline 1479 & 500 \\
\hline 1482 & 500 \\
\hline 1484 & $500^{35}$ \\
\hline 1485 & 500 \\
& 27.160 \\
\hline 1486 & - \\
\hline 1488 & - \\
\hline 1489 & 33.100 \\
\hline 1490 & 2.000 \\
\hline & 24.605 \\
1491 & 2.000 \\
& 26.100 \\
\hline
\end{tabular}

\section{LOS JUDEOCONVERSOS}

José Amador de los Ríos afirmaba que con motivo de las violencias antisemitas que asolaron Castilla en 1391, hubo una ola de conversiones entre los hebreos, que optaron por abrazar el cristianismo antes de ser sacrificados como mártires de la religión judía, “... precipitándose en las iglesias pidiendo a gritos las aguas bautismales...»36. Este movimiento de pánico generalizado alcanzó a muy diversas aljamas castellanas. Entre las pertenecientes al Reino de Toledo, el erudito historiador menciona la de El Puente del Arzobispo. Aunque ya hemos hecho alusión a la más que probable

34 En relación al "servicio y medio servicio" tomamos los datos de LADERo QUESADA, Miguel Ángel: "Las juderias de Castilla según algunos "servicios" fiscales del siglo XV", Sefarad, XXXI (1971), pp. 249-264, y VIÑUALES FERREIRO, Gonzalo: “El repartimiento del "servicio y medio servicio" de los judios de Castilla de 1484, 1485, 1490, y 1491 ", Sefarad (en prensa). Para los datos del impuesto de los "castellanos de oro", Vid.: SuÁREZ FERNÁNDEZ, Luis: Documentos acerca de la expulsión de los judios, Valladolid, 1964, pp. 65-72.

35 Hemos indicado esta cantidad en letra negrita ya que es la única vez que en la documentación se alude a la comunidad de judios de El Puente del Arzobispo como aljama.

36 AMAdOR DE Los Rios, José: Historia social, política, y religiosa de los judíos de España y Portugal, Madrid, 1875 (reimp. 1960), p. 483. 
temprana ocupación judaica de la villa, resulta difícil creer que la comunidad judía asentada como muy pronto en 1390, pida angustiosamente el bautismo al año siguiente. $Y$ más dífícil aún que en el transcurso de un año se haya configurado como una importante aljama, y menos cuando estaba alejada de las vías de penetración del movimiento violento, y bajo soberanía del arzobispo, que desearía con sus privilegios atraer el poblamiento de la villa, entre otros el de los judíos.

Nuestras evidencias acerca de los primeros judeoconversos de la villa nos conducen a fines de la décimoquinta centuria. Solamente gozamos de un testimonio de cristianos nuevos vecinos de El Puente del Arzobispo anterior a la expulsión de los judíos de 1492. En 1489, el Santo Oficio procesaba en efigie, pues entonces ya había fallecido, a Inés González, mujer que fue de Luis González, tejedor. Se la acusaba de cumplir los preceptos sabáticos, y observar los hábitos alimentarios propios de los judíos ${ }^{37}$.

Bastantes años más tarde serían también procesados por la Inquisición acusados de criptojudaísmo, dos vecinos de la citada localidad. Entre 1514 y 1515 fue juzgada Francisca Álvarez, hija de Luis Álvarez, pellejero, y casada con Diego Herrador. $Y$ entre 1530 y 1531, el Santo Oficio procesó a Francisco de Torres, a quien condenó a pesar de haber sido asesinado por sus compañeros de celda en la cárcel inquisitorial.

Otros vecinos de la localidad también padecieron la acción implacable de los jueces inquisitoriales en la primera mitad del siglo XVI, aunque los delitos de los que fueron acusados hacian ya referencia a la blasfemia, palabras escandalosas, o por haber incumplido las prohibiciones de la inhabilitación, etc.

\section{La inhabilitación en El Puente del Arzobispo}

Ahora bien, sabemos que la comunidad judeoconversa de la localidad debía ser algo más numerosa pues entre los judaizantes habilitados por el Santo Oficio, o entre sus descendientes, entre 1495 y $1497^{38}$, se mencionan diversos vecinos de la villa:

- Catalina Gómez, mujer de Alonso Martínez: 3.000 mrs.

- Elvira, muger de Sebastián Herrero: 500 mrs.

37 En su proceso declara como testigo, Diego de Villarroel, quien expone que «... vido muchos viernes en las noches candiles ençendidos con muchas mechas a casa de Luis González e de su muger, defuntos, vecinos de la Puente, e asimismo vido a la muger del dicho Luis González muchas vezes purgar la carne...", AHN. INQ. Leg. 154. Exp. 4.

38 CANTERA BuRgos, Francisco, y LEÓN TELLO, Pilar: Judaizantes del arzobispado de Toledo habilitados por la Inquisición en 1495 y 1497, Madrid, 1969, p. 139. 
- Costança Gonzáles, muger que fue de Alonso Gonzáles Menzorro: $250 \mathrm{mrs}$.

- María, hija de Pedro Sánchez, zapatero: $1.000 \mathrm{mrs}$.

- Alonso Rodríguez, guantero: 500 mrs.

- Isabel Ruiz de Guadalupe: $100 \mathrm{mrs}$.

- Diego Garcia, herrador, con 7 hijos menores: $3.000 \mathrm{mrs}$.

- Sancho Giménez, e su mujer: $5.000 \mathrm{mrs}$.

- Fernando Giménez, e su mujer: 5.000 mrs.

- Álvaro de Piedrabuena: $3.000 \mathrm{mrs}$.

- Fernando de Piedrabuena, su hermano: $1.000 \mathrm{mrs}$.

- Gonzalo de Piedrabuena, su hermano: $1.000 \mathrm{mrs}$.

- Garcia de Piedrabuena, su hermano: $1.500 \mathrm{mrs}$.

- Isabel Ferrández, su madre: 500 mrs.

- Elena, mujer de Pedro Sánchez, zapatero, por su hija: 300 mrs.

Aunque no supone una cantidad muy elevada, hemos de valorar como significativos los $30.650 \mathrm{mrs}$. que la Inquisición recauda para permitir que hijos y/o nietos de condenados pudieran usar de oficios prohibidos, o vestir ropas no autorizadas.

Mari García «... mujer que fue de Diego Loçano, herrador, de edad de çinquenta años..., es fija de Diego Garçía, herrador, christiano viejo, e de Isabel Garçía, su mujer, confesa, vecinos desta villa, e que la dicha su madre fue condepnada en Toledo, en la Santa Inquisiçión, abrá cuarenta e çinco años..." 39. Durante toda su vida ha vestido tocas y camisas labradas en seda, y anillos de plata, cosas prohibidas por el delito de inhabilidad. Ella sabe, pues su padre siempre se lo había dicho, que tenía habilidad para poder vestir esas ropas. No obstante, ante la solicitud de ese documento por parte de los jueces inquisidores debió abonar 3 ducados de oro, pues no fue capaz de encontrarlo.

A pesar de que el delito por el que la Inquisición juzgó a Isabel González, casada con el escribano de la villa, Martín Gómez, fue el de palabras escandalosas, su abuelo, Diego Jiménez, vecino de Guadalupe (Cáceres) fue condenado. Afirma en su testificación que jamás ha usado ninguna cosa prohibida, pero que además, tenía habilidad, aunque "... se la hurtó una moza con otras cosas...» 40 .

Los últimos datos que poseemos acerca de inhábiles de El Puente del Arzobispo se remontan hasta 1515. En el Archivo Histórico Nacional de Ma-

\footnotetext{
39 AHN. INQ. Leg. 119. Exp. 27.

40 AHN. INQ. Leg. 203. Exp. 25.
} 
drid, hemos encontrado un memorial de inhábiles de diversos lugares de la diócesis de Toledo. En él se incluyen los inhabilitados de esta localidad toledana, algunos de los cuales ya se registraban en las listas de fines del siglo Xv. Aquellos que no coinciden con el listado anterior son:

- Francisco Núñez, hijo de Juan de Villareal, y nieto de Fernando García de Piedrabuena.

- Costanza Fernández, mujer de Lope Sánchez.

- Juan Jiménez, hijo de Sancho Jiménez.

- Marisa Sánchez, mujer de Juan de la Puente.

- Juan de Plasencia, cristiano nuevo de judío.

- Mari Núñez, mujer de Antón Cabeza de Vaca.

- Cristóbal Rodríguez.

- Isabel González, mujer de Martín Gómez, escribano.

- Mari García, mujer de Diego Lozano.

En total contabilizamos un total de 34 vecinos de El Puente del Arzobispo que habían comprado su habilitación por ser descendientes de condenados por el Santo Oficio, en el período de tiempo comprendido entre 1495 y 1515.

Enemistad entre conversos: El proceso de Francisco de Torres.

Un dato nuevo en el que queremos incidir por la novedad y la originalidad de los testimonios es el asesinato que en la cárcel de la Inquisición sufrió Francisco de Torres, zurrador, natural de EI Puente del Arzobispo. Ya hemos hablado de él. Casado en cuatro ocasiones, este converso, del que ignoramos su nombre de judío, emigró en 1492 a Portugal. Fue bautizado en la iglesia mayor de Nuestra Señora de la Seo en la localidad portuguesa de Évora. Poco después, regresó a su lugar de origen, con su testimonio de conversión, y alli volvió a casarse, viviendo con, por lo menos, una hija. Sus padres, y abuelos, habían abandonado Castilla tras el decreto de expulsión de 1492, y habían muerto judíos "... allende...". Algunos testigos ya habían declarado los comportamientos judaizantes de este converso en alguna de las visitas que la Inquisición llevó a cabo en la villa toledana en 1500 y 1515.

No obstante, le hallamos en 1531 en la cárcel de la Inquisición de Toledo, compartiendo celda con Diego de Centeno, tejedor de lienzos, vecino de Guadalajara, y con Alonso Garçón, que residía en Alcalá de Henares. Había sufrido tormento pues de los testimonios de los testigos traslucía un evidente comportamiento judaizante. 
Pero el procedimiento hubo de zanjarse con el reo ya muerto. Los acontecimientos se sucedieron rapidisimos. La noche del 29 de abril de 1501, tras la cena, de la que el asesinado había probado escaso bocado, Francisco de Torres le pidió a Alonso Garçón, unas tijeras para «... hacerse la barba inferior...». Algo más tarde, su dueño, se las volvió a pedir para afilar una vela, y se las devolvió de nuevo. Entre las dos y las tres de la madrugada el alcalde de la Inquisición, Juan de Ortega, oyó voces muy altas y muchos golpes procedentes de una de las celdas de la prisión, pues desde alli venía el lamento de otros presos que afirmaban que su compañero se estaba muriendo.

Hasta esa celda bajó el alcalde, con la compañía de su mozo de cárcel, Juan Sánchez, donde hallaron a Francisco Torres, bien vestido, con algunas manchas de sangre en las manos y en la cara, tumbado del lado izquierdo y calzado. Al revisarle vieron que tenía las tijeras clavadas en el corazón. Estaba frío, y no daba la impresión de haberse muerto hacía poco rato. Además, en su bolsa encontraron un buen cuchillo de hierro, que aunque tenía la punta algo desgastada, bien le hubiera servido para suicidarse. $Y$ pudieron comprobar que la "barba inferior», causa por la que solicitó a su compañero de celda las tijeras, no estaba arreglada.

Todos estos indicios hicieron suponer a los inquisidores cierta sospecha sobre la culpabilidad de ambos compañeros de celda. Por tanto, el Santo Oficio los sometió a un duro tormento, y aunque no parece razonable el motivo del suicidio, les absolvió por falta evidente de pruebas. A su vez, la Inquisición condenó al fallecido confiscándole todos sus bienes.

Este relato algo tétrico nos conduce a una realidad de fondo algo más compleja que debemos preguntarnos. En primer lugar, analizar si el Santo Oficio, aún a sabiendas de la culpabilidad de los reos les deja en libertad para poder afrontar mejor la condena del muerto. Esta cuestión no podemos sino enunciarla y dejarla abierta, pues la solución no parece clara.

En segundo lugar, es significativo el odio y enemistad que puede provocar el criptojudaísmo entre los conversos. La principal causa que alega Diego de Centeno para tenerle odio a Francisco de Torres, es el hecho de que éste siempre andaba deseoso de convertirle al judaísmo. Así lo afirma en su declaración el mismo oficial de la cárcel, Juan de Ortega, pues testifica que había oído decir «... al dicho Centeno que queria mal al dicho Francisco de Torres, el qual ... trabajaba por bolver judío al dicho Centeno, e que avian pasado cinco meses y medio muy malos...". Una opinión que confirma también el mozo de la cárcel, Juan Sánchez.

La descripción que el otro reo hace del citado asesinado no es nada favorable, y demuestra que también estaba enemistado con él. Afirma que “... es hombre vano y muy fanfarrón, y mal cristiano, porque él fingia ser can- 
tor gracioso y buen tañedor de vihuela de arco y de acordes, y componedor, y que habia tenido ofiçio de padre de las mujeres de la mancebia y bodeguero y pertiguero y mercader de pescado y sardinas, ansi fresco como salado, y sea bailador y muy gran trabajador y maestro en las viñas y cortidor, y dezía muchas vezes como el año de la pestilencia bibía de enterrar muertos y con si viguela alegrando a las gentes por las calles...". De este relato se desprende el odio y enemistad que le tenían al mencionado converso.

Quizá en el fondo se exprese el miedo que tenían los otros reos a haber sido delatados por su compañero de celda ${ }^{41}$.

\section{Judíos que retornaron bautizados}

Una gran cantidad de noticias relativas a los conversos de El Puente del Arzobispo derivan del retorno de diversos judíos que habían regresado como cristianos a su población de origen. No obstante, algunos de aquellos que salieron de Castilla murieron en el exilio y serán sus hijos quienes regresen para exigir la devolución de muchos de los bienes que les habian pertenecido. Gracias a estos documentos podemos conocer algunos de estos casos de retornados.

La cercanía de la frontera portuguesa de Alcántara o Badajoz posibilitó el que muchos judíos quisieran mantener sus creencias frente a la obligatoriedad de convertirse al cristianismo, lo que les obligó a salir de Castilla. El movimiento de retorno debió ser sentido y considerable, pues Vernal Sánchez, zapatero, declara el 16 de julio de 1500 en la Puebla de Guadalupe que "... puede aver siete o ocho años, quando tornaron los judíos a Castilla, ya christianos..." 42. Una impresión que parece generalizada, pues en 1514-1515, Catalina García, mujer de Juan de Herrera, cardador, que declara en el proceso por judaizante contra Francisca Álvarez, afirma que "... conosçe a la dicha Francisca Álvarez de chiquita que le paresçe a este testigo que nasçió después que los judios volvieron a Castilla..." 43.

Resulta verdaderamente ejemplificador, acerca de los motivos que indujeron a los exiliados a regresar, el testimonio de varios testigos que participaron en el proceso contra Francisco de Torres, vecino de El Puente del Arzobispo, y juzgado por criptojudaísmo entre 1530 y 1531 . En él se insertan

41 Diego Centeno expone a los jueces inquisitoriales que la noche en que fue hallado muerto Francisco de Torres, éste habia exclamado cuando les trajeron la cena, «... aquello parece la sopa que Judas habia dado a Christo...", porque pensaba que habia declarado ante los inquisidores contra él.

42 AHN. INQ. Leg. 186. Exp. 1.

$43 \mathrm{AHN}$. INQ. Leg. 133. Exp. 13. 
algunas declaraciones que ante los jueces inquisitoriales realizaron otros vecinos de la villa en 1500. Vernal Sánchez, zapatero, vecino de la localidad cacereña de la Puebla de Guadalupe dice ante los representantes de la Inquisición que hacia 1493 estando en esa población de Cáceres, «... estava alli un christiano nuevo que cree que se llama Francisco y es natural de la Puente del Arzobispo, y es çurrador, e començaron a hablar con él e le dixeron que por qué se había ydo, e que entonçes habló Francisco de la Cruz, [otro de los testigos] e dixo: si el Rey nuestro señor mandase a los christianos que se tornasen judios o se fuesen de sus reynos, algunos se tornarían judíos e otros se yrían. E los que se fuesen desque se viesen perdidos tornarse y an judios por volverse a su naturaleza e que serian christianos e rezarian como christianos e engañarian al mundo: pensarian que heran judíos e de dentro en el coraçón e voluntad serían christianos...", a cuyo comentario el acusado asintió sin titubeos ${ }^{44}$.

Es curioso el caso de Francisco de Torres, converso asesinado en la cárcel de la Inquisición en 1531, del que sus compañeros de celda declaran acerca de las preocupaciones que llevaba camino de Portugal. En el interrogatorio de Diego de Centeno, tejedor de lienzos, vecino de Guadalajara contesta de este modo a las preguntas de los inquisidores:

- «... Preguntado que son las cosas que le vio hazer o dezir este testigo de mal hombre al dicho Francisco de Torres dixo que porque el suso dicho hablaba con este testigo de cosas de judios que le avian acaesçido yendo a Portugal...".

- «... Preguntado si comunicaba el dicho Francisco de Torres con este testigo las juderias que habria confesado haber fecho, el dicho Francisco de Torres, dixo que ni se las dixo ni se las comunicó...".

- "... Preguntado que cosas le dixo el dicho Francisco de Torres que le avian acaesçido yendo a Portugal e acá, le dixo que avia llevado una Atorá a Portugal, e que la habia dado en pago de çiertos dineros a unos menores parientes suyos que el uno se llamava Moxico, e un tio que se decia Ahim Canario, e que reñía muchas vezes con este el dicho Francisco Torres...".

Éstas eran, por tanto, las preocupaciones de los judíos camino de Portugal. No llegó muy lejos pues se convirtió en la villa portuguesa de Évora, el «... año de la conversión general de los judios de Castilla...", entonces en

44 Esta opinión la corrobora otro de los testigos presentes en esa conversación. Así, Francisco de Cáceres, también vecino de la Puebla de Guadalupe confirma que Francisco de la Cruz, otro de los testigos, le puso un ejemplo a Francisco de Torres, judeoconverso de El Puente del Arzobispo, acerca de la conversión de los judios que habian vuelto de Portugal y éste afirmó que esa era la explicación más verdadera. Expuso que ".. si el Rey de Castilla fuese judio e mandase a todos los christianos se tornasen judíos o se fuesen del reino, yrse $y$ an fasta que se viesen perdidos $e$ que después dirian tornémonos judios en el nombre como quier que en el coraçón seamos christianos...". Vid. AHN. INQ. Leg. 186. Exp. 1. 
1492, pues afirma, en 1530-1531, que “... avrá treinta e ocho años poco más o menos...". Fue bautizado en Nuestra Señora de la Seo, que era Iglesia Mayor, aunque no recuerda ni el nombre del sacerdote ni el de los padrinos que intervinieron en el sacramento.

El lugar de destino de los judíos de El Puente del Arzobispo en 1492 fue Portugal. La cercanía de la frontera portuguesa, las Relaciones ... afirman que "... la raya de Portugal estaba a 30 leguas...", hizo que todos los exiliados buscaran salida por las fronteras de Badajoz o Alcántara. Ya hemos aludido al caso de Francisco de Torres. También sabemos que, Diego de Silvera, Rodrigo Nieto, Fernando de Alcázar, Enrique de la Torre, Juan Díaz, y Juan de Toro, en la petición que elevaron ante el Consejo Real el 26 de octubre de 1493 solicitando la devolución de las heredades que les habian pertenecido en la dicha villa, «... al tiempo que nos mandamos salir los judios fuera de nuestros Reynos ellos seyendo judios se fueron al Reyno de Portugal...» 45. Francisca Álvarez, juzgada también por criptojudaísmo en El Puente del Arzobispo en 1514-1515, era hija de Luis Álvarez, pellejero, del que se comenta que «... estuvo en Portugal...» 46. Un testimonio que también corrobora, María, conversa en Portugal, que reclama en 1494 a los hospitales de la villa, la devolución de ciertos bienes sitos en esa localidad 47 .

No siempre regresaría toda la familia. Sabemos que Enrique de la Torre y su mujer salieron como judíos a Portugal. No obstante, él se ha convertido al catolicismo pero “... su muger no ha querido bolverse e que estava en el Reyno de Portugal judía...»48.

De acuerdo a la documentación se desprende que los judíos que vivían más próximos a la frontera fueron más proclives a portar consigo aquellos productos que según las leyes castellanas estaba prohibido llevarse fuera de los reinos ${ }^{49}$. Así da la impresión tras leer cómo el 2 de mayo de 1498, los Reyes Católicos ordenan a Gonzalo de Alcaraz y a Sebastián de Lobatón, que investiguen «... para saber quales personas de las villas de Talavera $e$ la Puente del Arzobispo e de las çibdades e villas e logares de los obispados de Plasencia, Coria e Badajoz, e Çibdad Rodrigo, e del Maestrazgo de

\footnotetext{
45 AGS. RGS. Fol. 33. [1493, octubre, 26.]

46 AHN. INQ. Leg. 133. Exp. 33.

47 AGS. RGS. Fol. 357. [1494, diciembre, 20.]

48 AGS. RGS. Fol. 345. [1494, febrero.]
}

49 Recordemos el texto exacto del edicto de expulsión de los judios con fecha de 31 de marzo de 1492: “... Y asimismo damos licencia y facultad a los dichos judíos y judias que puedan sacar fuera de todos los dichos nuestros reinos y señorios sus bienes y hacienda por mar y por tierra, con tanto que no saquen oro ni plata ni moneda amonedada ni las otras cosas vedadas por las leyes de nuestros reinos, salvo mercaderias, y que no sean cosas vedadas, o en cambios...". Vid. PÉREZ, Joseph: Historia de una tragedia. La expulsión de los judios de España, Barcelona, 1993, p. 150. 
Alcántara, e de la provincia de León...» 50, habian cometido el citado delito, y debian abonar una multa en compensación.

La comisión de este delito por parte de los cristianos nuevos de la villa de El Puente del Arzobispo debió de ser notoria, pues ya el 30 de enero del mismo año, (1498), los reyes, Isabel y Fernando, habían enviado una comisión al bachiller Sebastián de Lobatón para que “... luego vayáis a las villas de Talavera e la Puente del Arçobispo e a sus logares e juredicciones e ayáis informaçión e hagáis pesquisa por quantas partes e maneras mejor pudierdes saber la verdad quien e quales personas sacaron destos nuestros reinos e señorios e regnos estraños e logares vedados por las dichas leyes...» 51 . Como vemos, en el plazo de cuatro meses se menciona a la localidad puenteña como sede y refugio de diversos conversos que sacaron de Castilla metales, monedas, y otros objetos, yendo como judíos a Portugal. Sin embargo, no tenemos otras referencias que atestiguen que se descubrió quiénes fueron culpables de ese delito y qué cosas habian llevado fuera consigo.

Además del ya mentado Francisco de Torres, de los otros 10 judíos que regresarían convertidos a la villa de EI Puente del Arzobispo desconocemos el lugar de su bautismo, pero debió realizarse en localidades portuguesas cercanas como Elvas, o incluso, en la misma ciudad de Évora.

Los Reyes Católicos habian dispuesto en su pragmática del 10 de noviembre de 1492 como condición indispensable para poder regresar a sus Reinos, no sólo el afirmar que estos judíos estaban convertidos, sino que tenían que presentar una prueba oficial de haberse bautizado, normalmente en Portugal, o en la misma frontera para poder volver a entrar a Castilla ${ }^{52}$. En su proceso por judaizante, Francisco de Torres, expone ante los jueces inquisidores que en su casa tiene testimonio de bautismo ${ }^{53}$.

Sus familiares le acompañaron en este destierro. Francisco de Torres afirma que tanto sus padres como sus abuelos murieron judíos. Si bien es cierto, que tres de sus cuatro mujeres, han sido conversas o descendientes de cristianos nuevos.

La recuperación de los bienes que les habian pertenecido cuando judios a ellos o a sus antepasados fue una de las cuestiones más arduas del regreso de judíos bautizados a Castilla. Reclaman sus casas, tierras, y bienes, que

50 AGS. RGS. Fol. 154. [1498, enero, 30.]

51 AGS. RGS. Fol. 162. [1498, mayo, 2.]

52 «... que traygan fe auténtica cómo reçibieron bautismo ... la qual dicha fe asimismo mandamos que traygan los que se convertieren en el dicho reyno de Portugal e quesieren entrar en los dichos nuestros reynos porque podamos ser çiertos cómo los dichos judíos se tornan christianos e non pueda aver en ello cautela nin simulaçión alguna...". Vid. SUAREZ FERNANDEZ, Luis: op. cit., p. 488.

53 «... E que en el testimonio que tiene en su casa de baptismo...". AHN. INQ. leg. 186. Exp. 1 
malvendieron al salir, por la prisa de la huída y la avaricia de los compradores, y ahora exigen les sean devueltos. Tendrán que probar que estaban bautizados, y demostrar que no habían sacado "cosas vedadas" de Castilla, y además, justificar que la venta se produjo por menos de la mitad de su justo precio, y por último, devolver, los dineros que se les hubieran entregado, más lo invertido en las mejoras de las casas o tierras. No obstante, a pesar del fantasma de la Inquisición a muchos de ellos este trajín les compensó ante las calamidades de su exilio. Veamos los casos de El Puente del Arzobispo.

Enrique de la Torre, Diego de Silvera, Rodrigo Nieto, y su mujer, Francisca, Antón Rodríguez, Juan Díaz, Juan de Toro, Francisco Sánchez, Fernando de Alcázar, y María son todos conversos del judaísmo o hijos de conversos, que como judios vendieron en 1492 los bienes que poseian en la localidad toledana de EI Puente del Arzobispo, debido al decreto obligatorio de expulsión o conversión. Tras haber emigrado, en principio a Portugal, y advirtiendo las dificultades que conllevaba el exilio, deciden entonces bautizarse y asi poder regresar a sus hogares, alli donde habian dejado sus casas, viñas, y heredades.

El 26 de octubre de 1493, varios de ellos ya han retornado a El Puente, pues en esa fecha elevan una petición a los Reyes para que les sean devueltas sus heredades, ya que su venta careció de legalidad ${ }^{54}$. Esta legítima reivindicación, aprobada y aceptada por los monarcas, conllevaba ciertos riesgos y enemistades. Principalmente procedentes de todos aquellos que tuvieron algo que ver en el proceso venta-compra de esas propiedades. Muchos, de todos es bien conocido, aprovecharon la urgencia y la angustia de los hebreos para con la complicidad de una marcha segura, sacar el máximo provecho de unas compras a un precio muy por debajo del razonable. Sus reivindicaciones no debieron ser bien acogidas en la villa. Y la sensación de inseguridad debía ser palpable ya que ese mismo día, obtienen de la Corona un seguro y amparo pues temen que Beltrán Dorador, y Cristóbal Ruiz, o sus parientes y paniaguados, puedan cometer violencias contra ellos 55 .

Es cierto que en la gran mayoría de los casos, los Reyes estuvieron a favor de la devolución de los bienes a los conversos o a sus descendientes. Pero no siempre ocurrió así. En El Puente del Arzobispo, Bárbara González, reclama que compró ciertas casas de don Salomón Adaroque (=Fernando de Alcázar), y exigía que ahora no debían quitarle esos bienes pues nadie le había dado posibilidad de plantear una defensa ante lo que ella consideraba un agravio. Los Reyes dispondrán que se retrase la entrega de esas propiedades al converso, hasta que se pueda escuchar la defensa de dicha mujer.

54 AGS. RGS. Fol. 33. [1493, octubre, 26.]

55 AGS. RGS. Fol. 59. [1493, octubre, 26.] 


\section{LISTA DE CONVERSOS RETORNADOS A EL PUENTE DEL ARZOBISPO}

1. ALCÁZAR, Fernando de (=Salomón Adaroque) [AGS. RGS. fol. 33] [1493, octubre, 26]

2. DÍAZ, Juan

[AGS. RGS. fol. 33] [1493, octubre, 26]

3. FRANCISCA

Mujer de Rodrigo Nieto.

[AGS. RGS. fol. 215] [1494, noviembre, 3]

4. MARÍA

[AGS. RGS. fol. 357] [1494, diciembre, 20]

5. NIETO, Rodrigo

Casado con Francisca.

[AGS. RGS. fol. 33] [1493, octubre, 26]

6. RODRÍGUEZ, Antón

Sastre.

[AGS. RGS. fol. 215] [1494, noviembre, 3]

7. SÁNCHEZ, Francisco

[AGS. RGS. fol. 384] [1494, julio, 24]

8. SILVERA, Diego de

[AGS. RGS. fol. 33] [1493, octubre, 26]

9. TORO, Juan de

[AGS. RGS. fol. 33] [1493, octubre, 26]

10. TORRE, Enrique de la [AGS. RGS. fol. 33] [1493, octubre, 26]

11. TORRES, Francisco de [AHN. INQ. Leg. 186. Exp. 1] 


\section{APÉNDICE DOCUMENTAL}

1493, octubre, 26. Barcelona.

Que se devuelvan sus heredades a Diego de Silvera, Rodrigo Nieto, Fernando de Alcázar, Enrique de la Torre, Juan Díaz, y Juan de Toro, vecinos de El Puente del Arzobispo, de igual manera, judíos conversos.

AGS. RGS. Fol. 33.

Don Fernando e donna Ysabel etc. A vos Gómez de Arévalo alcalde mayor en la villa de la Puente del Arçobispo e a otras qualesquier justiçias de la dicha villa salud e gracia. Sepades que Diego de Sylvera e Rodrigo Nieto e Fernando de Alcaçar e Enrique de la Torre e Juan Díaz e Juan de Toro vecinos desta dicha villa nos fisieron relaçión por su petiçión que ante nos en el nuestro [Consejo] presentaron disiendo que al tiempo que nos mandamos salir los judíos fuera de nuestros Reynos ellos seyendo judíos se fueron al Reyno de Portugal, e que al tiempo que se yvan dis que vendieron los bienes rayses que asy tenían algunas personas, e que después que ellos se convirtieron a nuestra santa fe católica e que se vinieron a la dicha villa e que como quier que han requerido a las personas que asy los compraron las dichas heredades que se las tornen e que ellos los quieren pagar los mrs. que por ellas les dieron con más las mejorías e gastos que por ellas han fecho, dis que no lo han querido faser poniendo a ello sus escusas e dilaçiones e que si asy pasase ellos resçibirian en ello mucho agravio e daño e nos suplicaron e pydieron por merçed sobre ello les mandásemos proveer e remediar con justiçia o como la nuestra merçed fuese e nos tovímoslo por bien por que vos mandamos que dando e pagando los suso dicho[s] Digo de Sylvera e Rodrigo Nieto e Fernando de Alcáçar e Enrique de la Torre e Juan Díaz e Juan de Toro, todos los mrs. que reçibieron por las dichas heredades con más las mejorias e gastos que en las tales heredades han fecho las personas que las compraron se las fagáys tornar luego libre e desembargadamente sin pleito e syn rebuelta alguna, e los unos ni los otros, etc. Dada en Barçelona a XXVI de otubre de noventa e tres annos. Yo el Rey. Yo la Reyna. Yo Juan de Colonia, secretario, etc. Sennalada. Don Álvaro lohannes, dottor. Antonius, dottor. Franciscus licenciatus. Petrus, dottor.

1493, octubre, 26. Barcelona.

Seguro y amparo a favor de los sobredichos que temen de Beltrán Dorador y de Cristóbal Ruiz, y de sus parientes y sus paniaguados.

AGS. RGS. Fol. 59.

Don Fernando e donna Ysabel e etc. Al nuestro justicia mayor e a sus lugartenientes ea los alcaldes de la nuestra casa e corte e chançellería e a todos los corregidores e alcaldes e otras justiçias qualesquier asy de la villa de la Puente del Arçobispo como de todas las otras çibdades e villas e lugares de los nuestros Reynos e señoríos e a cada uno de vos salud e gracia. Sepades que Diego de Sylvera e Rodrigo Nieto e Fernando de Alcáçar e Enrique de 
la Torre e Juan Díaz e Juan de Toro, vecinos de la dicha villa nos fisieron relaçión por su petiçión que ante nos en el nuestro Consejo presentaron disiendo que ellos se temen e reçelan que por odio e malquerençia que con ellos han e tienen Beltrán Dorador e Cristóbal Ruiz e sus omes e criados e parientes e paniaguados e otros cavalleros e personas que ante vos las dichas justiçias él entiende nombrar e declar [declarar] por sus nombres les querian matar ferir e lisyar e prender e embargar e faser algún mal daño e desaguysado alguno en su[s] presonas [personas] e bienes contra derecho e justiçia o como no deva, en lo qual sy asy pasase que ellos reçibirían mucho agravio e daño, e nos suplicó e pidió por merçed sobre ello le mandásemos proveer e remediar con justiçia o como la nuestra merçed fuese e nos tovímoslo por bien e por la presente tomamos e reçebimos a los suso dichos e a sus omes e criados so nuestro seguro e amparo e defendimiento real e os aseguramos de los suso dichos e de sus omes e criados e parientes e paniaguados e de otros cavalleros que ante vos las dichas justiçias nombraren e declararen por sus nombres de quien dixeren que se temen e reçelan para que los no maten ni fieran ni lisien ni prendan ni embarguen ni fagan ningún mal daño ni desaguisado alguno con su[s] presonas [personas] e bienes contra derecho e justiçia e como no devan. Porque vos mandamos que guardéis esta carta de seguro e la fagáis a pregonar por las plaças e mercados e otros logares acostumbrados destas çibdades e villas e lugares por pregoneros e ante escribano público e sy después de fecho el dicho pregón sy alguna persona fuese o pasase contra esta carta de seguro vos las dichas justiçias pasades e procedades contra los todos e sus bienes a las mayores penas çevyles e crimynales que fallardes por derecho o como contra aquellos que pasan e quebrantan seguro puesto por carta e mandado de su Rey e Reyna, señores naturales, e los unos ni los otros, etc. Dada en Barçelona a veynte e seys días de otubre de noventa e tres años. Yo Yo (sic) el Rey. Yo la Reyna. Yo Juan de Colonia, secretario, etc. Sennalada Don Álvaro lohannes, dottor. Andrés, dottor. Antonius, dottor. Franciscus, licenciatus.

1494, abril, 21. Medina del Campo.

Incitativa a Gómez de Arévalo, alcalde de El Puente del Arzobispo, para que se devuelvan a Diego de Silvera, vecino de dicha villa, los bienes vendidos a bajo precio al salir del reino como judío.

AGS. RGS. Fol. 345.

Don Fernando e donna Ysabel, etcétera. A vos, Gómez de Arévalo alcaide e alcalde (sic) de la villa de la Puente del Arçobispo e alcalde en la dicha villa, salud e graçia. Sepades que Diego de Sylvera, vecino de la dicha villa nos fizo relaçión por su petiçión que ante nos en el nuestro Consejo presentó diziendo que al tiempo que se fueron los judios destos nuestros Reynos diz que el dicho Diego de Sylvera vendió tres pares de casas que él e vos sus hermanos tenía en censo ynfiteosín de los ospitales de la dicha villa, e que podria aver diez meses que fueron alumbrados de la graçia del Espíritu Santo e se convirtieron a nuestra Santa Fe Católica, e él ansy convertido diz que queria demandar las dichas casas que así diz que vendió e que uvo dellos que los avien comprado un par dellas diz que las avían tornado a vender a otra persona en la qual dicha venta que el dicho Diego de Sylvera diz que fue engañado en más de la mitad del justo preçio que nos suplicava e pedia por merced e remedio de justicia le mandásemos proveer mandándole tomar las dichas tres pares de casas e qualquier pregón que las cogiese dándole e pagándole el dicho Diego de Syl- 
vera los mrs. que asy resçibió de la dicha venta más las mejorías que en ellas ovieren fecho segund que esto e otras cosas más largamente en la dicha petiçión suya. $E$ por nos visto fue acordado que devíamos mandar dar esta nuestra carta para vos en la dicha raçón e nos tovímoslo por bien. Por que vos mandamos que sy el dicho Diego de Sylvera resçibió engaño de la dicha venta de las dichas tres pares de casas o en qualquier dellas en más de la mitad de su justo preçio que llamadas e oydas las partes a quien nos libremente e de plazo e syn dar logar a luengas ny dilaçiones de maliçia fagades e administredes en el dicho pleito por vuestra sentençia o sentençias aquello que fallaredes por justo por manera que el dicho Diego de Sylvera la aya e alcançe, e por defe[c]to della non tenga raçón de se quexar sobre ellos e los unos e los otros, so pena de XM mrs. etcétera, demás e etcétera. Dada en la noble villa de Medina del Campo a veinte e un días de abril de noventa e quatro años lo qual vos mandamos que fagades e cumplades pidiéndolo en el término que las leyes de nuestros reynos disponen. Don Álvaro Johannes, dottor. Andrés, dottor. Gundisalvus, licenciatus. Franciscus, dottoribus. Johannes, licenciatus. Yo Luis del Castillo, e etcétera.

\section{IV}

1494, julio, 24. Segovia.

A los alcaldes de Valverde que determinen la demanda que Francisco Sánchez, vecino de Villafranca de El Puente del Arzobispo, acerca de unas casas y bienes que su madre dejó en dicha villa al tiempo que los judíos salieron del reino, algunos vendidos a bajo precio, los cuales pide se le tornen, pagando él los precios por los que se habian vendido.

\section{AGS. RGS. Fol. 384.}

Don Fernando e donna Ysabel etc. A vos los alcaldes de la villa de Valverde e a cada uno de vos, salud e gracia. Sepades que Francisco Sánchez vecino de la villa de Villafranca de la Puente nos fiso relaçión por su petiçión e etc. diziendo que al tiempo que salieron los judíos destos nuestros Reynos, su madre dexó unas casas en esa dicha villa lindadas so çiertos linderos e otros bienes algunos vendidos por muy baxos preçios e otros diz que no pudo vender ni le dieron lugar para ello, e pues él se convirtió a nuestra santa fe católica que nos suplicava e pedía por merçed sobre ello le proveyésemos mandando que todos los bienes e casas que la dicha su madre avía quedado e fincado le fuesen quedados e entregados e restituidos pagando los preçios por que se avían vendido o como la nuestra merçed fuese. $E$ nos tovímoslo por bien porque vos mandamos que sy asy es que los dichos bienes que vendió la dicha madre del dicho Francisco Sánchez en esa dicha villa fueron vendidos por la meytad menos del justo preçio e pertenesçen al dicho Francisco Sánchez el derecho dellos e lo demandar dentro de los quatro años que el derecho quiere costringáis e apremiéis a las personas que los compraron que si vendieron otros bienes rayses para los comprar a que cumplan el justo preçio pagando el dicho Francisco Sánchez las quantías de mrs. por que fueron vendidos a las personas que las compraron e más lo que en ella ovieren mejorado a que los buelvan e entreguen e restituyan libre e desembargadamente e los unos ni los otros e etc. Dada en la çibdad de Segovia a XXIIII de jullio de XCIIII annos. Don Álvaro, don Juan de Castilla. Antoninus, dotor. Gundisalvus, licenciatus. Franciscus, licenciatus. Yo Bartolomé Ruy de Castañeda e etc. 
1494, octubre, 9. Madrid.

Amparo a Bárbara González, vecina de El Puente del Arzobispo, en la posesión de unas casas situadas en esta villa y compradas al judío Salomón Adaroque, al tiempo de su salida del reino, el cual convertido con el nombre de Fernando de Alcázar, reclama su devolución.

AGS. RGS. Fol. 110.

Don Fernando e donna Ysabel e etc. A vos los alcaldes e otras justiçias qualesquier de la villa de la Puente del Arçobispo salud e gracia. Sepades que Bárbara González, vesina desta dicha villa nos hiso relaçión por su petiçión disiendo que al tiempo que los judíos se fueron e absentaron destos nuestros Reynos ella ovo comprado de Salamón Adaroque que así se llamaba Ferrando de Alcáçar, unas casas que son en la dicha villa las quales él tenía a çenso de los ospitales de la dicha villa con su licençia por çierto presçio e quantía de mrs. e que agora se teme e reçela que por virtud de una nuestra carta que al dicho Ferrando de Alcáçar mandó dar para que le fuesen restituidos e tornados los bienes que vendió al tiempo que se fue destos nuestros Reynos restituyendo lo que así dio por ellas que sin ella ser llamada la despojarían de las dichas casas no aviéndole notificado la dicha nuestra carta para que ella pudiese alegar de su justiçia en lo qual dixo si asy pasase que ella resçibiria mucho agravio e daño, nos suplicó e pidió proçeder della con reconocimiento de justiçia le proveyésemos como la nuestra merçed fuese. E nos tovímoslo por bien porque vos mandamos a todos e a cada uno de vos que si asy es que al tiempo que la dicha Bárbara González fiso la dicha venta de las dichas casas no ovo ni intervino en ella engaño ni menos de la mitad del justo preçio e fasta aqui no le ha seydo yntimada la dicha nuestra carta, la [manchadoldes e defendades en la posesyon de las dichas casas e no consintades ni dedes lugar que dellas sea despojada e desapojada (sic) ni desapoderada ni que sobre ello le molesten ni ynquieten contra derecho fasta tanto que primeramente sea sobre lo suso dicho llamada a juisio e oyda e venida por fuero e por derecho ante quien como deva. $E$ los unos ni los otros e etc. Dada en Madrid a IX de octubre de XCIIII. Don Álvaro Johannes, dotor. Antón, dotor. Gundisalvus, licenciatus. Filipus, dotor. Petrus, dotor. Yo Luis de Castillo, etc.

1494, noviembre, 3. Madrid.

A las justicias de Villafranca de El Puente del Arzobispo, a petición de Antón Rodriguez, sastre, vecino de esa villa, y de Francisca, mujer de Rodrigo Nieto, vecina de El Campillo, judios conversos, que reclaman los bienes que vendieron sus padres al tiempo de la salida del reino o que se les abone su justo precio.

AGS. RGS. Fol. 215.

Don Fernando e donna Ysabel etcétera. A vos los alcaldes e otras justiçias qualesquier de la villa de Villafranca de la Puente del Arçobispo, salud e gracia. Sepades 
que Antón Ferrández, sastre, vecino desta dicha villa e Francisco Martínez de Romero vista del Campillo nos fisieron relaçión etcétera, disiendo que ellos fueron judíos e que al tiempo de que nos mandamos dar salir destos nuestros Reynos los judios que en ellos avian dis que sus padres vendieron çiertos bienes rayses que tenían en esta dicha villa por çiertas contías de mrs. mucho menos del justo preçio e que después que ellos se convirtieron a nuestra santa fe católica e vinieron a esta dicha villla, requirieron a las personas que los compraron que ge las tornasen resçibiendo dellos los mrs. por quales vendieron los dichos sus padres e dis que no to han querido faser en lo qual dis que ellos han resçebido mucho agravio e daño e nos suplicaron e pidieron por merced pues ellos se avian tornado cristianos los mandásemos tornar los dichos bienes que los dichos sus padres avían vendido a cada uno lo que vendió e como la nuestra merced fuese e nos tovímoslo por bien por que vos mandamos que sy asi es que los dichos sus padres siendo judíos e al tiempo que se yvan destos nuestros reynos nos vendieron los dichos bienes en la dicha villa por menos de la mitad del justo preçio e el padre e la madre son muertos e ellos son sus fijos e herederos llamadas e oydas las partes costringáys e apremiéis a las personas que los compraron a que suplan el justo preçio de todo ello e paguen e ge los restituyan los dichos sus bienes que así compraron tornándogelos dichos Antonio Rodríguez e Francisco, los mrs. que por ellos resçibieron los dichos sus padres al tiempo que se fueron destos nuestros Reynos e más los reparos e mejorías que en ellos ayan fecho con tanto que para la compra dellos no ayan vendido bienes rayses por manera que alcançen complimiento de justiçia e non tengan rasón sobre ello se nos venir a quexar e los unos nin los otros, etcétera. Dada en la villa a tres días de Noviembre de XCIV annos. Don Álvaro lohannes, dotor. Andrés, dotor, Gundisalvus, licençiatus. Petrus dottor, Yo Cristóbal de Vitoria.

VII

1494, noviembre, 12. Madrid.

Comisión a petición de don Álvaro de Piedrabuena, vecino de Villafranca de El Puente del Arzobispo, sobre que unos bienes que compró de procedencia judia se los reclama ahora Rodrigo Chacón, vecino de Talavera, alegando ser de su propiedad.

AGS. RGS. Fol. 342.

Don Fernando e donna Ysabel etcétera. A todos los corregidores asistentes alcaldes e otras justiçias qualesquier de todas las çibdades e villas e logares de los nuestros reynos e señoríos e cada uno e qualquier de vos a quien esta nuestra carta fuere mostrada, salud e gracia. Sepades que Álvaro de Piedrabuena vecino de la villa de Villafranca de la Puente del Arçobispo nos fiso relaçión, etcétera, disiendo que al tiempo que nos mandamos salir los judíos destos nuestros Regnos dis que un judío que se llamava Yudá Aday el qual dis que tenía buena fasienda e que dello vendió por si mismo e alguna cosa de los bienes que tenia por virtud de una carta que nos mandamos dar para que pudiesen dexar fatores para los vender e que el dicho judio lo ovo dexado en la dicha villa para sus fatores para poder vender los bienes que le quedaban a un Alonso Amos e a otras personas, vecinos de la dicha Villafranca segund más 
complidamente dis que se contiene en el poder e facultad que le dexó al dicho tiempo de su partida las quales dis que por virtud del dicho su poder ellos ovieron vendido unas casas e un majuelo que son en la dicha villa e sus términos, las quales dichas casas vendieron a vos Diego García cordobés, vecino que fue de Siruela, e a Pedro Rodríguez de Syruela por çierta contía de mrs. que con ellos se conçertaron e que el dicho majuelo vendieron al dicho Álvaro de Piedrabuena ansy mismo por çierta contía de mrs. e que después los dichos Diego Garçia, cordobés, e Pedro Rodríguez de Syruela, compradas las dichas casas e poseyéndolas ellos que las tornaron a vender al dicho Álvaro de Piedrabuena por más dineros de los quales avían costado e que agora un Rodrigo Chacón vecino de la villa de Talavera dise que le perteneçen las dichas casas e majuelo disiendo que los dichos fautores non las pudieron vender e en la venta que fisieron a los suso dichos e a el que es ninguna e que pide que le despoje de la posesión de las dichas casas e majuelo en lo qual si ansy oviese de pasar reçibirian mucho agravio e daño, e nos suplicó e pidió por merced sobre ello le mandásemos proveer e remediar con justiçia o como la nuestra merced fuese, e nos tovímoslo por bien. Por que vos mandamos que luego veáis lo suso dicho e llamadas e oídas las partes a quien atañe lo más brevemente e sin dilaçión que se pueda non dando logar a luengas ni dilaçiones de maliçia, fagáys e administréis al dicho Álvaro de Piedrabuena entero e breve complimiento de justiçia e por defecto della non tengan cabsa ni rasón de se nos más quexar sobrello. E los unos nin los otros etcétera. Dada en la villa de Madrid, a XII de noviembre de XCIV annos. Don Álvaro lohannes, dotor. Andrés, doctor. Antonio Filipus, doctor. Ivannes licençiatus. Yo Cristóbal de Vitoria, escribano, etcétera.

\section{VIII}

\section{4, noviembre, 18. Madrid.}

Incitativa a las justicias de Villafranca de El Puente del Arzobispo sobre la devolución de los bienes que vendió al tiempo de su salida del reino el judío converso Fernando de Alcázar, vecino de dicha villa.

AGS. RGS. Fol. 216.

Don Fernando e donna Ysabel etcétera. A vos los alcaldes e otras justiçias qualesquier de la villa de Villafranca de la Puente del Arzobispo, salud e gracia. Sepades que Ferrando de Alcázar vecino desta dicha villa nos fiso relaçión etcétera, disiendo que el hera judio e que al tiempo que nos mandamos salir los judíos que en ellos avían dis que él vendió çiertos bienes que él tenía en esta dicha villa por çiertas contías de mrs. por mucho menos de la mitad del justo preçio e que después que él se convirtió a nuestra santa fe católica e vino a esta dicha villa e requirió a las personas que los compraron que ge los tornasen resçibiendo ellos los $\mathrm{mrs}$. por que los vendieron, dis que no to han querido faser en lo qual dis que ha resçebido mucho agravio e dapno e nos suplicó e pidió por merced que pues él se avía tornado cristiano les mandásemos tornar los dichos sus bienes que avia vendido o como la nuestra merced fuese. $E$ nos tovimoslo por bien, por que vos mandamos que si así es, que el dicho Juan de Alcázar seyendo judio al tiempo que se yva destos nuestros Reynos, vendió los dichos bienes en esta dicha villa por menos de la mitad del justo preçio e llamadas e oydas las partes 
costringáis e apremiéis a las personas que los compraron a que suplan el justo preçio del todo ello e paguen o que les tornen e restituyan los dichos bienes que ansy compraron tornando el dicho Ferrando de Alcázar los mrs. que por ellos resçibió al tiempo que se fue de estos nuestros Reynos e más los reparos e mejorías que en ellos avían fecho con tanto que para la compra dellos non ayan vendido bienes raices por manera que alcançen complimiento de justiçia e sobre ello non tengan cabsa ni razón de se nos más quexar. Dada en la villa de Madrid a dies e ocho dias de Noviembre de XCIV annos. Don Álvaro lohannes, doctor, Andrés, doctor, Antonio, doctor, Gundisalvus, licenciado. Yo Cristóbal de Vitoria.

\section{IX}

\section{Medina del Campo.}

Incitativa a Gómez de Arévalo, alcalde de las torres de El Puente del Arzobispo, y alcalde de la villa, a petición de Enrique de la Torre, vecino de la misma, reclamando el importe de unas casas vendidas a bajo precio al salir de España, por ser judio.

\section{AGS. RGS. Fol. 345.}

Don Ferrando e donna Ysabel, etcétera. A vos Gomes de Arévalo alcayde de las torres de la Puente el Arçobispo e alcalde de la dicha villa, salud e gracia. Sepades que Enrrique de la Torre, vecino de la dicha villa, nos fyso relaçión por su petyçión que ante nos en el nuestro Consejo presentó disiendo que al tiempo que se fueron los judíos destos nuestros Reynos dis que el dicho Enrrique e su muger ovieron vendido una casa que tenya a ençenso ynfiteosyn de los ospitales de la dicha villa, e que podía aver un anno que él alumbrado de la graçia del Espíritu Santo se convirtyó a nuestra Santa Fe Católica e que la dicha su muger no ha querido bolverse e que estava en el Reyno de Portugal judia e que el dicho Enrrique quisyera demandar la dicha casa e la sacar del comprador pagándole los maravedies por que asy fue vendida e que el dicho comprador dis que la vendió al mayordomo de los dichos ospitales en la qual dicha venta que el dicho Enrrique e la dicha su muger fysyeron dis que fueron y sacados en más de la mitad de su justo preçio. Por ende por nos suplicava e pedía por merced con remedio de justiçia le mandásemos proveer mandándole tomar la dicha su casa a qualquier persona que la toviese, dándole e pagándole el dicho Enrrique los mrs. que ansy reçibió de la dicha venta más con las mejorias que en ella ovieron fecho segund que esto e otras cosas más largamente en la dicha petyçión se contenía e por nos vista fue acordado que devíamos mandar dar esta nuestra carta para vos en la dicha razón. Porque vos mandamos que si el dicho Enrrique resçibió engaño en la venta de la dicha casa en más de la mitad del justo preçio que llamadas e oydas las partes a quien atañen libremente e de plano sin dar logar a luengas ni dylaçiones de maliçia, libredes e determynedes en el dicho pleyto por vuestra sentençia o sentençias aquello que falláredes por justo, por manera que el dicho Enrrique la aya e alcançe e por defe[c]to della no aya cavsa ni Rasón de se nos venir ni embiar a quexar ante nos, e non fagades ni fagan ende al etcétera. Dada en la villa de Medina del Campo a [blanco] días del mes de a [blanco] anno del nasçimiento de nuestro Salvador lhesu Christo de mill e quatroçientos e noventa e quatro años. 


\section{$\mathrm{X}$}

1495, mayo, 9. Madrid.

Merced a Pedro Sánchez de Valdemoro de la sinagoga de El Puente del Arzobispo con todo lo que a ella pertenecía, según y como la posee por donación que de ella le hizo el Cardenal de España.

AGS. RGS. Fol. 6.

Don Fernando e donna Ysabel, etc. Por quanto por parte de vos Pero Sánchez de Valdemoro nos fue fecha relaçión que el Reverendo Cardenal de España, arçobispo de Toledo, nuestro primado vos ovo fecho graçia e donaçión por virtud de la merced que nos le ovimos fecho de los bienes de los judíos de las villas de logares del arçobispado de Toledo de la Xinoga de la Villafranca de la Puente del Arçobispo e con el prado e casas e corrales e con todas las otras casas que son anexas a la dicha xinoga segúnd más largamente se contiene en la provisión que dello vos dio e segund que lo poseían e tenían los judíos de la dicha villa de la Puente antes que fuesen destos nuestros reynos por virtud de la qual vos tomases la posesión de la dicha Xinoga e cosas suso dichas e que vos toméys e reçebáys que vos será çierto e seguro lo sobre dicho por virtud de la dicha donaçión que dello vos fizo suplicándonos vos mandásemos faser merced dello o como la nuestra merced fuese e nos acatado algunos serviçios que vos avedes fecho tovímoslo por bien. E por la presente vos fasemos merçed $e$ donaçión de la dicha Xinoga de la dicha villa de la Puente del Arçobispo e con él prado e casas e corrales e con todas las otras cosas que son anexas a la dicha Xinoga segund en la dicha provisión que dello el dicho Cardenal vos dio se contiene. $E$ avemos por buena e firme la posesión que por virtud della tomases e avedes la qual dicha merced vos fasemos segund dicho es para vos e para vuestros herederos e subçesores e para quien de vos e dellos ovieren cabsa para al por jamás para que podades vender e dar e donar e sacar e cambiar e enajenar por qualquier título la dicha Xinoga e cosas suso dichas a ella anexas e faser dellas e en ellas lo que quisierdes e por bien tovierdes como de cosa vuestra propia libre e desembargada e mandamos al concejo justicia e regidores oficiales e omes buenos de la dicha villa de la Puente e otros qualesquier nuestros jueses que son o fueren de los bienes de los judíos en el dicho arçobispado e otras qualesquier personas a quien toca e atañe lo suso dicho que vos guarden e cumplan e fagan guardar e complir esta merced que nos vos fasemos en la manera que dicha es e que vos defiendan e amparen en la posesión de la dicha Xinoga e casas e corrales e prado e otras cosas a ella anexas e contra ello vos non vayan ni pasen ni consientan yr ni pasar ni por alguna ni por alguna (sic) manera la qual dicha merçed vos fasemos en la manera que dicha es con tanto que sy algunos mrs. hayan situados en la cabeça de pecho e serviçio e medio serviçio de los judíos de la dicha villa de la Puente del Arçobispo aquellos ayáis de pagar a la persona o personas que los tenían situados de valor de la dicha Xinoga e casas e corrales e prado e otras cosas anexas a la dicha Xinoga por quanto aquellos son bienes comunes de la aljama de los judíos de la dicha villa de la Puente, e estavan obligados al tal situado, e los unos nin los otros non fagades ni fagan ende al por alguna manera so pena de la nuestra merced e de dies mill mrs. para la nuestra cámara e demás mandamientos al ome que vos esta nuestra carta mostrare que vos emplaze que parescades ante nos en la nuestra Corte doquier que nos seamos del día que vos fasta quinse días primeros siguientes so la dicha pena so la qual mandamos a qualquier escribano público que para esto fuere llamado que dende al que vos la mostrare testimonio sygnado con su signo porque nos sepamos en como se cumple nuestro mandado. Dada en la villa de Madrid a nueve días del mes de mayo anno del nasçimiento del nuestro Salvador Ihesu Christo de mill e quatroçientos e 
noventa e çinco annos. Yo el Rey. Yo la Reyna. Yo Juan de la Parra, secretario del Rey e de la Reyna nuestros señores la fise escrevir por su mandado, en forma, Rodericus, doctor.

1498, enero, 30. Alcalá de Henares.

Comisión al bachiller Sebastián de Lobatón, para que haga pesquisa sobre los judios que sacaron cosas vedadas de Talavera y El Puente del Arzobispo, cuando fueron expulsados.

A.G.S. R.G.S. Fol. 154.

Don Fernando e Doña Isabel, etc. a vos el bachiller Sebastián de Lobatón, salud e gracia. Sepades a nos somos informados que al tiempo que por nuestro mandado fueron echados fuera destos nuestros Reynos los judíos, algunos dellos que agora son convertidos a nuestra santa fe católica, e otras personas, ovieron sacado fuera destos dichos nuestros Reynos contra las leyes e hordenanzas dellos oro e plata e moneda monedada e otras cosas por nuestro mandado e pramáticas proebidas por que incurrieron en las penas contenidas en las dichas leyes que en tal caso disponen e por que nuestra merçed e voluntad es demandar proveer cerca de lo suso dicho para que las penas en que tales personas incurrieron sean en ellas e en sus bienes executadas segund lo disponen las dichas leyes e confiando de vos que sóis tal persona que guardaréis nuestro servicio e bien e fielmente haréis lo que por nos vos fuere mandado e encomendado, acordamos de vos cometer e encomendar e por la presente vos lo encomendamos e cometemos e vos mandamos que luego vayáis a las villas de Talavera, e la Puente del Arzobispo e a sus lugares e juredicciones e ayáis informaçión e hagáis pesquisa por quantas partes e maneras mejor pudierdes saber la verdad quien e quales personas sacaron destos nuestros Reynos e señoríos e regnos estraños e logares vedados por las dichas leyes oro o plata o moneda o otras cosas defendidas e los a ello dieron consejo favor e ayuda e así avida la dicha informaçión e sabida la verdad pongáis en nuestro nombre fiscal que los acuse ante vos e llamadas e oydas las partes a quien tocare breve e sumariamente determinéis sobre aquello de que fueren acusados por vuestras sentençias interlocutorias e definitivas lo que fallardes por fuero e por derecho llevando e mandando llevar las tales sentençia e sentençias a devida execuçión e efecto proçediendo contra las personas e bienes de los culpados segund la calidad del negoçio lo requiere e si para lo suso dicho o qualquier cosa dello favor e ayuda ovierdes menester mandamos por esta nuestra carta o su traslado signado de escrivano público para los conçejos corregidores justiçias regidores cavalleros escuderos ofiçiales e omes buenos de las dichas villas e cada una dellas e de otras partes qualesquier que seyendo por vos requeridos vos lo den e presenten e fagan dar e prestar a qualesquier personas de qualquier estado o condiçión que sean, parescan ante vos e vengan a vuestros llamamientos e emplazamientos para ser de ellos informados e para lo otro que por vos les fuere mandado so las penas que vos de nuestra parte les pusierdes e mandardes poner las quales nos desde agora les ponemos e avemos por puestas e vos damos poder complido para las executar en las personas e bienes de los que rebeldes e inobedientes fueren e para todo lo suso dicho e cada cosa e parte dello con todas sus incidençias e emergençias anexidades e conexidades e dependençias es nuestra merçed e voluntad que estéis en hazer lo suso dicho treinta días e que ayáis de salario cada día dozientos e treinta mrs. e para un escrivano, setenta mrs. los quales podades aver e cobrar de los que en lo sobre dicho hallardes culpados 
vendiendo sus bienes que para ello bastante en pública almoneda e rematándolos en la persona o personas que más por ellos dieren entregándovos el dicho vuestro salario de los mrs. que valieren para lo qual ansí mismo vos damos poder complido e los unos nin los otros non fagades nin fagan ende al, por alguna manera so pena de la nuestra merçed e de diez mil mrs. para la nuestra cámara e demás mandamos al ome que vos esta nuestra carta mostrare que vos emplaze e parezcan ante nos seamos del día que los emplazare fasta quinze días primeros siguientes so la dicha pena so la qual mandamos a qualquier escrivano público que para esto fuere llamado que de ende al que ge la mostrare testimonio signado con su sino porque nos sepamos en como se cumple nuestro mandado. Dada en la villa de Alcalá de Henares a treinta días del mes de henero anno del nasçimiento de nuestro señor Ihesu Christo de mil e quatroçientos e noventa e ocho annos. Yo el Rey. Yo la Reina. Yo Gaspar de Gazio, secretario del Rey e de la Reina de nuestros señores la fize escrevir por su mandado. En forma, Rodericus doctor.

\section{XII}

1498, marzo, 20. Alcalá de Henares.

Prórroga del plazo que se había dado al bachiller Sebastián de Lobatón para que hiciese pesquisa en las villas de Talavera y El Puente del Arzobispo, sobre las personas que sacaron oro y plata al tiempo de la salida de los judíos.

AGS. RGS. Fol. 504.

Don Fernando e donna Ysabel a vos el bachiller Sevastián de Lobatón, salud e gracia. Sepades que nos vos ovimos mandado yr a las villas de Talavera e la Puente del Arçobispo e sus tierras para faser pesquisa e sobre la verdad que personas de las dichas villas e sus tierras sacaron e fueron e sacar[on] destos nuestros Reynos al tiempo que los judíos fueron de ellos e otros por ellos oro plata e moneda e otras cosas vedadas e los que a ello dieron favor consejo e ayuda para que contra los que hallésedes en ello culpados e contra sus bienes en cierta manera e en çierto término según más largamente en nuestra provisión que sobre ello vos mandamos dar se contiene, e porque el término que para ello vos mandamos dar es cumplido e acabado e nuestra merçed e voluntad es de vos mandar prorrogar el dicho término e estender la dicha comisión que vos ovimos dado para las çibdades e villas e lugares de los obispados de Plasençia e Coria e Badajoz e de la Provinçia de León, e del Maestradgo de Santiago e del Maestradgo de Alcántara, vos mandamos que acabado de determynar lo sobre dicho de las dichas villas de Talavera e La Puente 0 antes sy posierdes, vayáis a los dichos obispados de Plasençia e Coria e Badajoz e çibdades e villas e lugares dellas e de la dicha Provinçia de León e Maestradgo de Alcántara e fagáys pesquisa e ynquisición por quantas partes mejor pudierdes saber la verdad de las personas que fueron culpantes en sacar de los dichos nuestros reynos e señoríos oro e plata e moneda e cosas vedadas e los que a ello dieron consejo favor e ayuda e porque ayáis en nuestro nombre f[ilegible] que los acuse ante vos a los que en ello hallardes culpados, e llamadas e oydas las partes a quien tocare e atañere proçedays contra ellos e sus bienes a todas las penas e las leyes e hordenamientos e pramáticas destos nuestros reynos e señorios que sobre disponen contenidas según el tenor e forma de nuestro poder e comisión que para las dichas villas de Talavera e la Puente vos mandamos dar e es nuestra merçed e voluntad que estedes en faser lo suso dicho quatro meses e que ayáis en cada un día para vos e un secretario el salario en la dicha nuestra provisión contenido e lo cobréys de los que fallerdes culpados 
para lo qual faser e cumplir e executar cada cosa e parte dello vos damos poder complido por esta nuestra carta según en la dicha nuestra provisión se contiene e sy para lo suso dicho favor e ayuda ovierdes menester por esta nuestra carta mandamos a los conçejos gobernadores corregidores alcaldes justiçias cavalleros comendadores alcaydes e otras qualesquier personas de qualquier estado o condiçión que sean e a cada uno dellos que seyendo por vuestra parte requeridos vos lo den e presten e fagan dar e prestar so las penas que vos devían por tales pusierdes e mandades poner para las quales executar en las personas e bienes de los que remisos e ynobedientes fueren vos damos poder complido con todas sus inçidençias emergençias anexidades e conexidades e pendençias e los unos nin los otros non fagades nin fagan ende al por alguna manera so pena de la nuestra merçed e de diez mil mrs. a cada uno que lo contrario hiziere para la nuestra cámara e de más mandamos al home que vos esta nuestra carta mostrare que vos emplaze que parezcades ante nos en la nuestra corte doquier que nos seamos de el día que vos emplazare fasta quinze días primeros siguientes so la dicha pena so la qual mandamos a qualquier escribano público que para esto fuere llamado que del día que vos emplazare ende al que vos la mostrare testimonio firmado con su signo por que nos sepamos como se cumple nuestro mandado. Dada en la villa de Alcalá de Henares a veynte dias de março de mill e quatroçientos e noventa e ocho annos. Yo el Rey. la [tachado]. Yo la Reyna. Yo Gaspar de Grizo etc. en forma licenciatus.

\section{XIII}

1498, mayo, 2. Toledo.

Que Gonzalo de Alcaraz, juntamente con el bachiller de Lobatón, que habia tenido comisión para entender de las desobediencias de las leyes que prohibian a los judíos sacar oro y plata de los reinos, en Talavera, El Puente del Arzobispo, obispados de Plasencia, Coria, Badajoz y Ciudad Rodrigo, maestrazgo de Alcántara, y provincia de León, hagan igualas con los dichos judios y que lo que se cobrase de las penas que se les pusiere, que lo deposite en una buena persona.

\section{A.G.S. R.G.S. Fol. 162.}

Don Fernando e Doña Isabel etc. a vos Gonzalo de Alcaraz salud e gracia. Sepades que nos siendo informados que al tiempo que para nuestro mandato fueron echados destos nuestros Regnos e señoríos los judíos, muchos dellos e otras personas sacaron e fueron en sacar oro e plata e monedas e otras cosas defendidas por nuestras leyes e premáticas, e otras personas dieron a ello consejo, favor e ayuda, por lo qual los unos e los otros cayeron e incurrieron en las penas de las dichas leyes e prematicas e çerca dello e para saber quales personas de las villas de Talavera e la Puente del Arzobispo e de las cibdades e villas e logares de los obispados de Plasençia, Coria e Vadajoz, e Çibdad Rodrigo e del maestrazgo de Alcántara e de la provincia de León, fueron en faser e cometer lo suso dicho o en ello dieron consejo, favor e ayuda, ovimos mandado e dado nuestro poder e comisión al bachiller Sebastián de Lobatón, e para contra los que fallase en ello culpados procediese en çierta manera segund que en las dichas nuestras cartas e provisiones que sobre ello le mandamos dar se contiene. E pues nuestra merçed e voluntad es que con las personas que por el dicho bachiller fueran condepnados por los fallar culpantes en lo suso dicho, algunos dellos serán tan pobres e de tal condiçión que procediendo contra ellos por rigor de justiçia aquí den e pa- 
guen las dichas condepnaçiones se les seguiria a los culpados asaz perdida e daño por nuestro poder complirlo lo que así son obligados a pagar. Por ende, nos confiando de vos que sóis tal persona que bien e fielmente guardarás nuestro servicio e farás lo que por nos vos fuere mandado e nuestro mandado por la presente nos mandamos e cometemos que vayades a las dichas cibdades e villas e lugares a que las dichas provisiones que al dicho bachiller mandamos dar se estiende e con las personas que bien visto vos fuere de los por el dicho bachiller son o fueren condepnados sobre lo qual en su condepna non podades igualar e convertir e componer juntamente con el dicho bachiller e no el uno sin el otro e lo que paresçiere e bien visto fuere a vos e al dicho bachiller con la parte e partes que así fueren condepnados aviendo respeto a las culpas e facultades que tienen e poseen asentamiento en vuestro registro la condepnaçión e secrestos del sus bienes e valor por quanto apreçiados e que bienes heran en la conveniençia porque son igualados e conçertarlos e por ello paguen la parte que bien visto vos fuere en los términos e plazos que para ello dierdes firmados señalando el dicho registro vos el dicho bachiller e el escrivano por ante quien pasaren las pesquisas e condepnaciones e secrestos e las cuantías de mrs. se acuda e acudan de los dar e pagar en el término que vos paresçiere a una buena persona que eligierdes que sea de confianza e abonada en cada una çibdad, villa e logar dellos cotenidos en las dichas provisiones a las quales dichas personas que así fueren por vosotros señaladas e nombradas mandamos que lo açepten e fagan so la persona o personas que de nuestra parte les pusierdes las quales por la presente nos les ponemos e avemos por puestas e que no se tomen de las dichas condepnaçiones por los e faser ninguna quantía ni le sean asçendido con ello ni parte dello mas que todo quede e finque en poder de las personas como dicho es quedando secrestados los tales bienes fasta aver complido e preguntado la tal iguala e asiento tomado e que vosotros o las dichas personas que fueren nombradas como dicho es para resçebir e cobrar las dichas cuantías de mrs. podades o puedan dar e otorgar carta o cartas de pago o descuento de los mrs. que de las dichas igualas e convenençias e compusiçiones se resçibieren e cobraren e las quales queremos que valan e sean firmes para agora e siempre como si nos las fiziésemos e otorgásemos para lo qual vido que dicho es e por cada una cosa o parte dello vos damos poder complido con todas sus incidençias e dependençias emergençias anexidades e conexidades. Dada en la çibdad de Toledo a dos días del mes de mayo anno del nasçimiento de nuestro salvador Ihesu Christo de mil e quatroçientos e noventa e ocho annos. Yo el Rey. Yo la Reina. Yo Gaspar de Grisco, secretario del Rey e de la Reina nuestros señores la fis escrevir por su mandado en las espaldas esta carta señalada del nombre de licenciado Çapata.

XIV

1515.

Memorial de inhábiles de los lugares de: El Puente del Arzobispo, Guadalupe, Herrera, La Puebla, Siruela, Capilla, Agudo, y Almadén.

AHN. INQ. Leg. 120. Exp. 41.

[2r]

- «[...] Garçía de Piedrabuena, vecino de la Puente del Arçobispo e Álvaro de Piedrabuena, vecino de la Puente del Arçobispo, no dize que ofiçios tienen e son defuntos, y 
Garçía de Piedrabuena, marido de Beatriz Alemán que hera bivo año 1542, ha de saber de estos Hernando y Garçía, moços, hijos de Álvaro de Piedrabuena [...]".

- «[...] Fernando de Piedrabuena, morador en la Puente, año 1514, y hera tendero e joyero, y también Francisco Núñez, nieto del dicho Ferrando Garçía [...]".

[5r]

- «[...] Hernán Ximénez, vecino de la Puente del Arçobispo dize en el dicho libro folio 164 que es inhábil e fue mayordomo del conçejo e que creen fue por ello penitençiado año $1524[\ldots] »$.

[6r]

- «[...] Costança Fernández, mujer de Lope Sánchez, vecina de la Puente, es reconciliada, dízelo ella en el dicho libro, fol. 286 [...]".

[6v]

- «[...] Juan Ximénez, hijo de Sancho Ximénez, dize el dicho libro, fol. 310, que fueron condenados en Guadalupe su padre de su padre, e su aguela también madre de su padre [...]".

- «[...] Marisa Sánchez, mujer de Juan de la Puente, vecina de la Puente del Arçobispo es fija de Pero Sánchez, condenado, en dicho libro, fol. 311, voçetur [...]”.

- «[...] Juan de Plazençia, vecino de la Puente del Arçobispo, el año 1514, diz en el dicho libro, fol. 312 , que es reconçiliado. Voçetur para saber lo que ha usado [...]".

[8r]

- «[...] Mari Núñez, mujer de Antón Cabeça de Baca, dize en el dicho libro, fol. 365, que es nieta de condenado de partes de su padre, boçetur [...]".

[9r]

- «[...] Cristóbal Rodríguez, natural de Toledo, hera vecino de la Puente del Arçobispo en 1514, y syendo reconciliado en Toledo, hera ally mayordomo del conçejo, y por esto fue penitençiado, boçetur [...]".

[9v]

- "[...] Ysabel González, mujer de Martín Gómez, escribano, dize en el dicho libro fol. 443, que es nieta de condenado porque el padre de Sancho Ximénez, su padre, fue condenado en Guadalupe [...]".

[13r]

[...] La Puente del Arçobispo:

- Juan de Plazençia, cristiano nuevo.

- Fernán Ximénez, carnicero.

- Mari Sánchez, mujer de Juan de la Puente.

- Francisco Núñez, hijo de Juan de Villarreal.

- Juan Ximénez, fijo de Sancho Ximénez.

- Mari Núñez, muger de Antón Cabeça de Baca.

- Ysabel González, muger de Martín Gómez, escribano. [...] 